\title{
The in Vivo Inhibition by $\beta$-Phenylserine of Rabies, Myxoma, and Vaccinia Viruses
}

\author{
MARCEL W. PONS ${ }^{1,2}$ AND WILLIAM S. PRESTON ${ }^{3}$ \\ Department of Bacteriology, East Medical Building, \\ University of Michigan, Ann Arbor, Michigan
}

Accepted June 14, 1961

\begin{abstract}
The daily intraperitoneal administration of $10-15 \mathrm{mg}$ of $\beta$-phenylserine protected rats against death from lethal amounts of rabies virus. The protective effect was most marked when the animals were treated for 3 days prior to the injection of the virus, although initiation of treatment 24 hours after the virus was injected also gave protection. The administration of DL-phenylalanine or DL-tyrosine in combination with $\beta$-phenylserine reversed the inhibition of rabies virulence. Rabies-infected animals protected with $\beta$-phenylserine and challenged with a second injection of rabies virus 6-7 weeks later did not show any immunity.

The xanthine oxidase activity of infected rat brain increased during the course of rabies. The increased activity paralleled the titer of virus in the brain. There was no alteration in the xanthine oxidase activity when animals injected with the virus were treated with $\beta$-phenylserine.

$\beta$-Phenylserine inhibited the propagation of vaccinia virus in rabbit skin when the compound and virus were mixed prior to injection. The daily intraperitoneal injection of $75 \mathrm{mg}$ of $\beta$-phenylserine delayed the development of myxomatosis in rabbits. The compound had no apparent effect on the multiplication of influenza A (PR8), eastern equine encephalitis, poliovirus (Lansing strain), or mouse encephalomyelitis (FA strain) viruses in mice. The compound was inactive also against influenza $A$ virus in embryonated eggs.
\end{abstract}

\section{INTRODUCTION}

Dickinson and Thompson (1957) showed that $\beta$-phenylserine inhibited influcnza A virus multiplication in chorioallantoic membrane fragments. The compound acted during the first half of the latent period and the inhibition could be reversed by phenylalanine.

Hosley (1955) found that $\beta$-phenylserine inhibited the multiplication of rabies virus in cultures of minced mouse brain but this inhibition could not be reversed by phenylalanine.

\footnotetext{
${ }^{1}$ Submitted in partial fulfillment of the requirements for the degree of Doctor of Philosophy in the University of Michigan.

${ }^{2}$ Present address: The Public Health Research Institute of the City of New York, Inc., Foot of Fast; 16th Street, New York, New York.

${ }^{3}$ Deceased.
}

In bacterial systems, $\beta$-phenylserine acts as a competitive inhibitor of phenylalanine hydroxylase. In mammalian cells in vitro this enzyme is inoperative (Eagle et al., 1957). The effect of the compound in vivo has not been investigated.

\section{MATERIALS AND METHODS}

Virus. A strain of rabies virus was isolated from a dog brain submitted for diagnostic study to the Pasteur Institute of the University of Michigan. The virus was passed intracerebrally five times in Swiss albino mice (weight 10-14 g), then twice by two passages in rats inoculated into the masseter muscle. A virus pool was prepared by injecting a 10\% suspension of infected mouse-brain into a number of Swiss albino mice (weight 10-14 g). These mice were sacrificed when prostrate with rabies. The 
brains were removed aseptically and ground in a mortar, with alundum or sand as the abrasive. A $20 \%$ suspension was prepared by the addition of distilled water. After removal of coarse particles of tissue by low speed centrifugation, the supernatant fluid was distributed in screw-cap vials in $1.3-\mathrm{ml}$ amounts and stored at $-45^{\circ} \mathrm{C}$ until needed. In the course of these investigations it was necessary to prepare seven such virus pools. Each pool prepared by this method had an intracerebral $\mathrm{LD}_{50}$ titer of approximately $3 \times 10^{-4.0}$ in Swiss albino mice.

Virus titrations. Titrations were carried out using serial tenfold dilutions of pool virus, injecting six mice at each dilution level intracerebrally with $0.03 \mathrm{ml}$ of virus or injecting six to ten rats into the masseter muscle with $0.03 \mathrm{ml}$ of virus at each dilution. Dilutions were made in buffered gelatin saline $(0.5 \%$ Bacto-gelatin in phosphate-buffered saline) and kept in an ice bath until all the animals had been inoculated. The $L D_{50}$ end points were calculated by the method of Reed and Muench (1938). The death of an animal within 96 hours after injection was considered nonspecific.

Xanthine oxidase determinations. The method of Bauer and Bradley (1956) was used to determine the amount of xanthine oxidase in rat brains. Albino rats of approximately the same age and weight as the test animals $(150 \pm 5 \mathrm{~g})$ were selected. At the proper times the animals were stunned by a sharp blow on the back and then decapitated. The brains were removed and placed in a chopped-ice bath. After weighing, the brains were ground in a mortar with an equal weight of sand, and borate buffer $(\mathrm{pH} 9.0)$ was added to give a $20 \%$ suspension. Large particles were removed by low speed centrifugation. Three-tenths milliliter of the rat brain suspension was placed in a test tube containing $0.25 \mathrm{ml}$ of a solution of 2,3,5-triphenyltetrazolium chloride $(20 \mathrm{mg} / \mathrm{ml})$ prepared fresh each third day and stored in the dark; $0.5 \mathrm{ml}$ borate buffer (pH 9.0$) ; 0.25 \mathrm{ml}$ of a solution of hypoxanthine $(0.26 \mathrm{mg} / \mathrm{ml})$; and sufficient water to bring the total volume to $2.25 \mathrm{ml}$. Blanks, which contained no substrate, were also prepared. The reaction vessels were shaken and placed in an opaque glass vacuum desic- cator which was sealed, evacuated, and placed in the $37^{\circ}$ incubator for 19 hours. At the end of the incubation period the red formazan was dissolved in $5 \mathrm{ml}$ glacial acetic acid and then extracted with $3 \mathrm{ml}$ toluene and $2 \mathrm{ml}$ acetone. The optical density at $495 \mathrm{~m} \mu$ was determined in a Bcckman DU spectrophotometer; the difference between the test and blank values gave a measure of the enzyme's activity. Determinations were made in triplicate, and the values obtained were divided by the dry weight of the brain to give the value: optical density per gram of brain (dry weight).

\section{RESULTS}

Preliminary experiments showed that the injection of $0.03 \mathrm{ml}$ of rabies virus into the brains of mice or the masseter muscles of rats consistently produced a fatal infection. This method was used as the standard procedure for examining the effects of the compound on virus multiplication in vivo. The intramasseter injection of a mouse brain suspension containing $100 \mathrm{LD}_{50}$ of rabies virus usually caused the death of rats in 14-18 days.

\section{Toxicity of $\beta$-Phenylserine}

In order to determine the toxicity of the compound, various concentrations were administered to albino rats weighing approximately $150 \mathrm{~g}$. It was found that a single dose of $200 \mathrm{mg} \beta$-phenylserine administered intraperitoneally would kill all the animals. When the animals received $20 \mathrm{mg} \beta$-phenylserine per day they all died in 9-10 days. Administration of $10-15 \mathrm{mg}$ per day for 1 month had no overt effect on the rats.

\section{Effect of $\beta$-Phenylserine on Rats Injected with Rabies Virus}

Pool virus with an intramuscular $\mathrm{LD}_{50}$ of $3 \times 10^{2}$ in rats was used in most of the test systems.

Each of three serial tenfold dilutions of virus was injected $(0.03 \mathrm{ml}$ into the masseter muscle) into 5 rats of approximately the same age and weight $(150 \mathrm{~g})$. Intraperitoneal administration of $1 \mathrm{ml}$ of $10 \mathrm{mg} / \mathrm{ml}$ $\beta$-phenylserine was begun 4 days prior to infection of the animals, so that the fourth injection of the compound and the virus 
were given simultaneously. Treatment was continued until the first animal in the group died of rabies. Infected animals treated with injections of water and untreated animals served as virus controls; uninfected animals treated with $\beta$-phenylserine served as controls for the compound. In this and subsequent experiments, all surviving animals were observed for 60 days before they were considered to be negative. The results summarized in Table 1 indicate that a significant degree of protection was obtained.

Since treating the animals with water did not alter the course of the infection and the dosage of $\beta$-phenylserine uscd was not toxic

\section{TABLE 1}

The Effect of $\beta$-Phenylaserine on Rabies INFECTION IN RATS

\begin{tabular}{c|c|c|c|c|c|c}
\hline \multirow{2}{*}{ Dilution } & $\begin{array}{c}\text { Phenylserine } \\
\text { treated }\end{array}$ & $\begin{array}{c}\text { Water } \\
\text { control }^{a}\end{array}$ & \multicolumn{2}{|c}{ Control } \\
\cline { 1 - 5 } & $\mathrm{D} / \mathrm{I}$ & $\mathrm{MIT}$ & $\mathrm{D} / \mathrm{I}$ & $\mathrm{MIT}$ & $\mathrm{D} / \mathrm{I}$ & $\mathrm{MIT}$ \\
\hline $10^{-1}$ & $1 / 5$ & 31.0 & $5 / 5$ & 20.0 & $5 / 5$ & 17.0 \\
$10^{-2}$ & $2 / 5$ & 26.0 & $5 / 5$ & 16.4 & $5 / 5$ & 18.4 \\
$10^{-3}$ & $0 / 5$ & - & $0 / 5$ & - & $1 / 5$ & 17.0 \\
$\mathrm{LD}_{50}$ & $10^{-0.87}$ & $10^{-2.6}$ & $10^{-2.5}$ \\
\hline
\end{tabular}

${ }^{a} \mathrm{D} / \mathrm{I}$, Deaths due to rabies virus per number inoculated; MIT, mean incubation time (days).

TABLE 2

The Effect of $\beta$-Phenylserine on Rabies INFECTION IN RATS ${ }^{a}$

\begin{tabular}{|c|c|c|c|c|}
\hline $\begin{array}{c}\text { Experi- } \\
\text { ment } \\
\text { no. }\end{array}$ & $\begin{array}{c}\text { Dosage } \\
\text { (mg/ } \\
\text { day) }\end{array}$ & $\begin{array}{c}\log _{10} \\
\mathrm{LD}_{50} \\
\beta \text {-Phenyl- } \\
\text { serine- } \\
\text { treated } \\
\text { pre-injection } \\
\text { (4 days) }\end{array}$ & $\begin{array}{l}\log _{10} \\
\operatorname{LD}_{50} \\
\beta-P h e n y l- \\
\text { serine- } \\
\text { treated } \\
\text { postin- } \\
\text { jection } \\
\text { (1 day) }\end{array}$ & $\begin{array}{c}\log _{10} \\
\operatorname{LD}_{50} \\
\text { Control }\end{array}$ \\
\hline 2 & 10 & 1.60 & 1.70 & 2.20 \\
\hline 3 & 10 & 1.08 & 1.52 & 2.70 \\
\hline 4 & 10 & $0.91^{b}$ & 1.00 & 2.70 \\
\hline 5 & 15 & $0.85^{b}$ & $0.93^{b}$ & 2.63 \\
\hline 6 & 15 & $0.79^{b}$ & $0.94^{b}$ & 2.67 \\
\hline
\end{tabular}

a Experiment 2, 6 animals were used per dilu tion; experiments $3-6,10$ animals were used per dilution.

${ }^{b}$ Calculated by probit analysis.

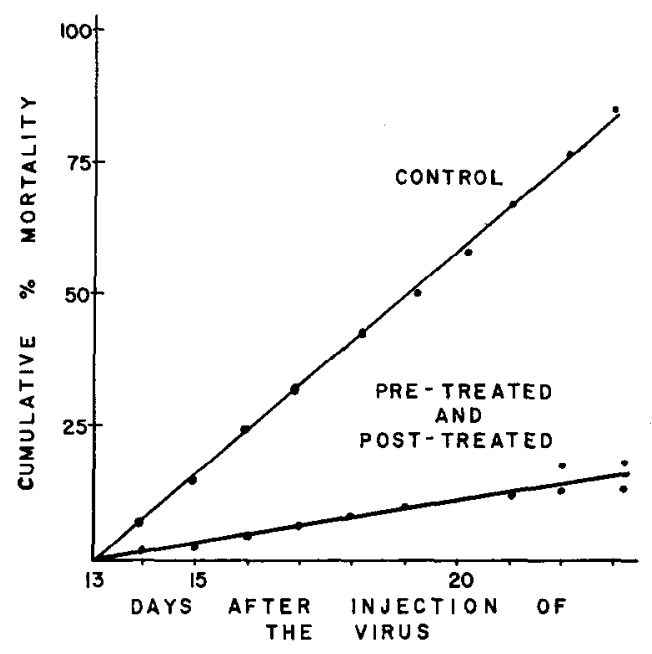

F'IG. 1. Inhibition of rabies infection in rats by $\beta$-phenylserine. Pooled results of several different experiments. Control: No $\beta$-phenylserine treatment. Treated animals received $15 \mathrm{mg} \beta$-phenylserine per day intraperitoneally for 10-14 days. Pretreated: Treatment begun 4 days prior to injection of virus. Posttreated: Treatment begun 24 hours after injection of virus.

for the animals, these controls were omitted in subsequent experiments and an additional group of animals was included. These animals began receiving daily injections of the compound 24 hours after injection of virus. The results of five experiments are summarized in Table 2.

The data from experiments 3-6 were combined and are represented graphically in Fig. 1. It can be seen that, by the nineteenth day, more than $50 \%$ of the animals in the control group were dead while the cumulative percentage mortality of the pre- and posttreated animals never exceeded $20 \%$. There was no important difference between the death rate in the pre- and posttreated groups, both of which showed that the animals were protected against the disease.

When the $\beta$-phenylserine dosage was increased to $15 \mathrm{mg} /$ day a somewhat greater degree of protection was obtained (experiments 5 and 6 ) ; however, $20 \mathrm{mg} /$ day proved to be toxic when administered for more than 8 days.

The protective effect was also demonstrated by injecting $90 \mathrm{LD}_{50}$ of virus into the masseter of sixty rats. Twenty began 
receiving the compound ( $15 \mathrm{mg} /$ day) 24 hours before challenge, twenty received the compound 24 hours after injection of the virus, and the remaining twenty served as controls. The mortality rates of the preand posttreated groups were $20 \%$ and $30 \%$, respectively, as opposed to $100 \%$ in the control group.

These experiments were carried out using a strain of albino rats supplied by the Upjohn Company, Kalamazoo, Michigan. When they were repeated using different strains of rats obtained from other sources, we were unable to demonstrate the same degree of protection, getting at best a difference of 0.5 to $0.8 \operatorname{logs}$ in the $\mathrm{LD}_{50}$ of treated and control groups.

Table 3 presents the results of an experiment in which 120 rats $(150 \pm 10 \mathrm{~g})$ were divided into two groups of sixty. Each of these groups was subdivided into 6 groups of 10 animals. All animals were injected with $90 \mathrm{LD}_{50}$ of rabies virus and 10 animals in group 1 and the 60 animals in group 2 received $15 \mathrm{mg}$ of $\beta$-phenylserine. Each day an additional 10 animals in group 1 began to receive the compound and continued to be treated until the first animal in the experiment died of rabies on day 11. In group 2 , treatment was stopped on subgroups of 10 animals each day. An additional 30 animals served as controls. The compound protected the animals when daily treatment was begun within 48 hours after injection of the virus. There was a slight indication that one injection of $15 \mathrm{mg} \beta$-phenylserine could protect an animal when this was administered at the time the virus was injected and that treatment for 6 days was not enough to give protection.

$\beta$-Phenylserine $(15 \mathrm{mg} / \mathrm{ml})$ in buffered gelatin saline was used to dilute rabies virus, which was injected into rats intramasseterly and into mice intracerebrally after 1 hour's incubation. There were no differences in the end points of control and cxpcrimental titrations. This led us to believe that the compound does not act directly on the virus.

\section{Reversal of $\beta$-Phenylserine Inhibition}

$\beta$-Phenylserine inhibition of bacteria can be reversed by the addition of excess phen-
TABLE 3

EFfect of Varying Time of Initiation and Termination of $\beta$-Phenylserine Treatment on Rabies Infection in Rats ${ }^{a}$

\begin{tabular}{cccc}
\hline $\begin{array}{c}\text { Com- } \\
\text { pound } \\
\text { begun } \\
\text { on day }\end{array}$ & $\mathrm{D} / \mathrm{I}^{b}$ & $\begin{array}{c}\text { Com- } \\
\text { pound } \\
\text { stopped } \\
\text { on day }\end{array}$ & $\mathrm{D} / \mathrm{I}$ \\
\hline 1 & $5 / 10$ & 1 & $7 / 10$ \\
2 & $6 / 10$ & 2 & $8 / 10$ \\
3 & $9 / 10$ & 3 & $9 / 10$ \\
4 & $9 / 10$ & 4 & $9 / 10$ \\
5 & $10 / 10$ & 5 & $8 / 10$ \\
6 & $9 / 10$ & 6 & $8 / 10$
\end{tabular}

"Experimental animals received a 1:50 dilution of the virus $\left(\operatorname{LD}_{50} 10^{-2.8}\right)$. Treatment: $15 \mathrm{mg}$ $\beta$-phenylserine intraperitoneally per day.

${ }^{b} \mathrm{D} / \mathrm{I}$, Deaths due to rabies virus per number noculated.

ylalanine or tyrosine. Dickinson and Thompson (1957) showed that $\beta$-phenylserine inhibition of influenza A virus multiplication in chorioallantoic membrane fragments could be reversed by phenylalanine.

'The effects of DL-phenylalanine and DLtyrosine were tested in rats injected intramuscularly with rabies virus. These compounds, both alone and in combination with $\beta$-phenylserine, were injected each day intraperitoneally in the amounts indicated in Table 4 . $\beta$-Phenylserine protected rats injected with the virus, but tyrosine or phenylalanine nullified the protection. Thus, it appears that the inhibitory action of $\beta$ phenylserine involves phenylalanine and tyrosine metabolism in the intact animal.

\section{Effect of Compounds Structurally Related to $\beta$-Phenylserine on Rats Injected with Rabies Virus}

Previous studies using antimetabolites have indicated that certain molecular groups in an inhibitor are responsible for its activity. In an attempt to determine the group or groups in the $\beta$-phenylserine molecule responsible for its protective effect, five compounds (Table 5) structurally related to the inhibitor were tested for their ability to protect animals inoculated with rabies virus. Treatment with the various compounds was begun on the day virus was inoculated and was continued until the first 
TABLE 4

Reversal of $\beta$-PhenYlserine InHibition with DL-Tyrosine and DL-Phenylalanine

\begin{tabular}{|c|c|c|}
\hline Compound $^{a}$ & $\begin{array}{c}\text { Dosage } \\
\text { (mg/day) }\end{array}$ & $\begin{array}{l}\log _{10} \\
\operatorname{LD}_{50} b^{b}\end{array}$ \\
\hline Tyrosine & 6 & 3.00 \\
\hline$\beta$-Phenylserine & 6 & 1.58 \\
\hline $\begin{array}{l}\text { Tyrosine plus } \beta \text { - } \\
\text { phenylserine }\end{array}$ & 6 (each) & 3.15 \\
\hline Tyrosine & 8 & 2.62 \\
\hline$\beta$-Phenylserine & 8 & 1.39 \\
\hline $\begin{array}{l}\text { Tyrosine plus } \beta \text { - } \\
\text { phenylserine }\end{array}$ & 8 (each) & 2.62 \\
\hline Phenylalanine & 10 & 2.83 \\
\hline$\beta$-Phenylserine & 10 & 1.00 \\
\hline $\begin{array}{c}\text { Phenylalanine plus } \\
\beta \text {-phenylserine }\end{array}$ & 10 (each) & 2.83 \\
\hline Control & - & 3.35 \\
\hline
\end{tabular}

${ }^{a}$ Animals began to receive compounds 24 hours after injection of virus.

${ }^{b}$ Ten animals per dilution.

animal died of rabies on the tenth day. The animals treated with $\beta$-hydroxypropionic acid became increasingly difficult to handle when they were injected; treatment of these animals was discontinued on the eighth day when it became impossible to hold them without being bitten. The results indicate that only $\beta$-phenylserine gave definite protection.

\section{Immunity to Rabies Virus after $\beta$-Phenyl- serine Treatment}

If $\beta$-phenylserine acted at an early stage in the development of the disease and prevented the growth of the virus, there should be little or no antibody response to the virus. Since the original challenge dose $(0.03$ $\mathrm{ml}$ of a $10^{-1}$ or $10^{-2}$ dilution) was so small, it should account for very little antibody production.

Twenty rats which had survived injection of rabies virus after treatment with $\beta$-phenylserine were divided into two groups; each group consisted of animals which had survived the injection of $10^{-1}$ and $10^{-2}$ dilutions of pool virus. Group 1 and group 2 were challenged intramuscularly with 50 $\mathrm{LD}_{50}$ of rabies virus 6 and 7 weeks, respectively, after the first virus inoculation. All the animals succumbed to the infection. The mean incubation time and the manifesta- tions of the disease did not differ from those for animals which had been injected with this amount of virus for the first time.

\section{The Effect of $\beta$-Phenylserine on Other Virus-Host Systems}

$\beta$-Phenylserine had no inhibitory effect on the multiplication in mice of eastern equine encephalitis, poliovirus (type 2, Lansing strain), mouse encephalomyelitis (FA strain), and influenza A (PR8) viruses. Preliminary experiments showed that the compound did inhibit the development of vaccinia and myxoma virus lesions in the rabbit.

\section{Vaccinia Virus}

Vaccinia virus propagated in eggs was used. Three separate intracutaneous titrations were done on the back of each rabbit used. Rabbits received virus diluted in saline $(0.2 \mathrm{ml})$, virus diluted in $\beta$-phenylserine $(15 \mathrm{mg} / \mathrm{ml})$, or virus diluted in saline and daily intraperitoneal injections of 75 $\mathrm{mg} \beta$-phenylserine. The results of three experiments are presented in Table 6. Although a significant degree of protection was obtained, the small number of animals used and the variations in the results will not allow of drawing any definite conclusions.

\section{Myxoma Virus}

Two rabbits were injected intradermally with $0.01 \mathrm{ml}$ of a $10 \%$ suspension of tissue

\section{TABLE 5}

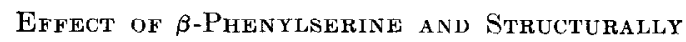

Related Compounds on Rats InJected With Rabies Virus

\begin{tabular}{lc}
\hline \multicolumn{1}{c}{ Compound $^{a}$} & $\log _{10} \mathrm{LD}_{50}{ }^{b}$ \\
\hline Phenyl pyruvate & 2.5 \\
Serine & 2.4 \\
Hydrocinnamic acid & 2.5 \\
Phenylglycine & 2.4 \\
$\beta$-Hydroxypropionic acid & 2.4 \\
$\beta$-Phenylserine & 1.32 \\
Control & 3.28
\end{tabular}

${ }^{a}$ Dosage of $\beta$-phenylserine and other compounds, $10 \mathrm{mg} /$ day intraperitoneally.

${ }^{b}$ Ten animals per dilution. 
TABLE 6

EFfect of $\beta$-Phenylserine on Vaccinia INFECTION IN RABBITS

\begin{tabular}{|c|c|c|c|}
\hline \multirow{2}{*}{ Treatment } & \multicolumn{3}{|c|}{$\begin{array}{l}\text { End points of intradermal } \\
\text { titrations }\end{array}$} \\
\hline & Expt. 1 & $\operatorname{Expt.~} 2$ & Expl. 3 \\
\hline $\begin{array}{l}\text { Control (virus di- } \\
\text { luted in saline) }\end{array}$ & $10^{-4}$ & $10^{-4}$ & $10^{-4.5}$ \\
\hline $\begin{array}{l}\text { Virus diluted in } 15 \\
\mathrm{mg} / \mathrm{ml} \beta \text {-phenylser- } \\
\text { ine }\end{array}$ & $10^{-2}$ & $<10^{-1}$ & $<10^{-1}$ \\
\hline $\begin{array}{l}\text { Virus diluted in sa- } \\
\text { line }+75 \mathrm{mg} \beta \text {-phen- } \\
\text { ylserine daily in- } \\
\text { traperitoneally }\end{array}$ & - & $<10^{-1}$ & $10^{-3}$ \\
\hline $\begin{array}{l}\text { Number of rabbits } \\
\text { per group }\end{array}$ & 1 & 3 & 3 \\
\hline
\end{tabular}

containing myxoma virus. One of two rabbits was treated with $75 \mathrm{mg}$ of $\beta$-phenylserine intraperitoneally daily. In the treated animal the lesion was slower in developing, compared to that of the control, and the animal lived 48 hours longer. These results suggested that $\beta$-phenylserine might have an effect on the propagation of myxoma virus.

Six rabbits were injected with $10^{4} \mathrm{LD}_{50}$. Three of the rabbits received $75 \mathrm{mg} \beta$-phenylserine intraperitoneally daily. The lesions approximated hemispheres; their volumes were measured daily and the average volumes of the lesions of the 3 control rabbits and the 3 treated rabbits were plotted as shown in Fig. 2. The deaths of treated animals were delayed by $24-48$ hours.

Another experiment was conducted using 12 rabbits. Three rabbits served as controls and were injected with $100 \mathrm{LD}_{50}$ of the virus while the remaining rabbits were injected with $100 \mathrm{LD}_{50}, 1000 \mathrm{LD}_{50}$, and $10,000 \mathrm{LD}_{50}$, using 3 rabbits at each dilution. The 9 latter animals received $75 \mathrm{mg}$ $\beta$-phenylserine intraperitoneally daily. The results, shown in Fig. 3 indicate that $\beta$ phenylserine caused a 3 -day lag in the development of the lesions in the rabbits which received $100 \mathrm{LD}_{50}$. It is of interest that only the control curve can be extrapolated back to the origin and that only this group and the $10,000 \mathrm{LD}_{50}$ group show truncated curves, indicating an immunological response to the virus.

\section{Alterations in the Xanthine Oxidase Ac-} tivity of the Brains of Rats Injected with Rabies Virus

Bauer and Bradlcy (1956) reported that in mice injected with neurotropic viruses the xanthine oxidase activity of the brain increases as the infection progresses. You-

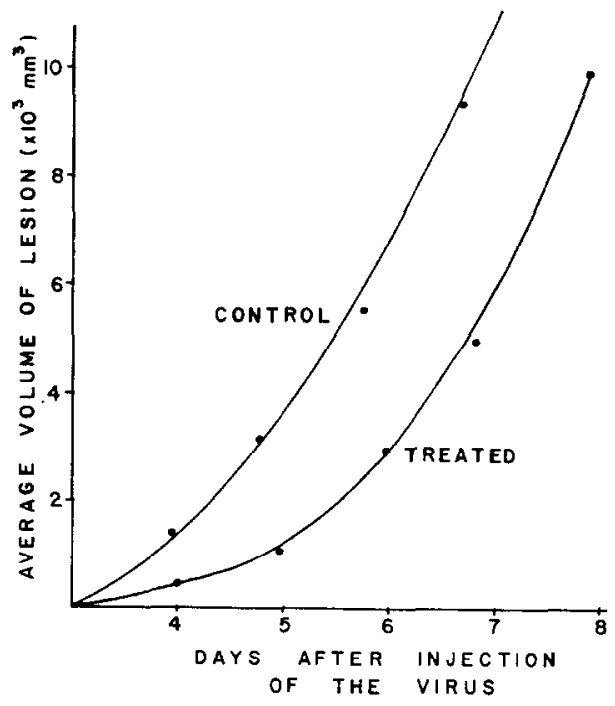

FIG. 2. Inhibition of myxomatosis in rabbits by $\beta$-phenylserine. Virus injected intradermally and $\beta$-phenylserine ( $75 \mathrm{mg} /$ day) was administered intraperitoneally from day 0 until the animals died. There were three rabbits in each group.

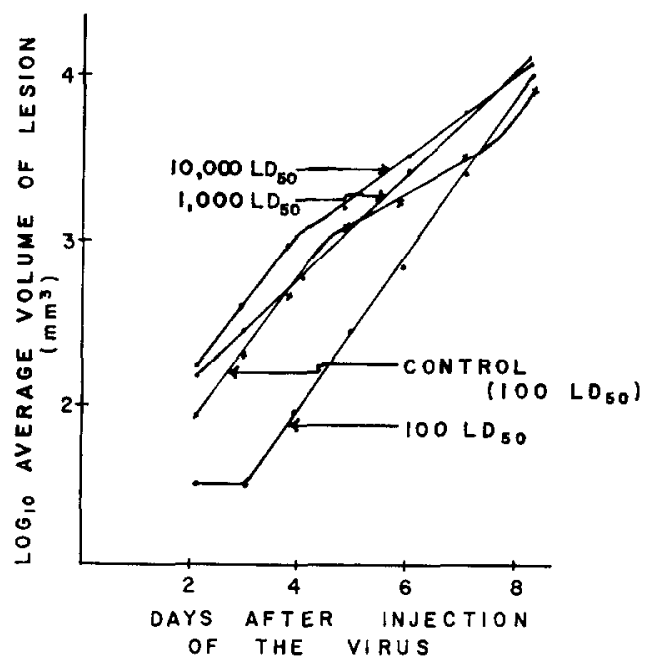

FIG. 3. Same as Fig. 2. 
nathan et al. (1956) have shown that $\beta-2-$ thienylalanine can cause a decrease in the xanthine oxidase activity of rat liver. Since the action of $\beta$-2-thienylalanine and $\beta$ phenylserine is similar in some systems, we compared the effect of $\beta$-phenylserine on the xanthine oxidase activity of the brains of normal rats and rats infected with rabies.

Five groups of 20 rats weighing 190-195 g were used. Group $1, \beta$-phenylserine controls, received $15 \mathrm{mg}$ of $\beta$-phenylserine daily. Group 2, virus controls, were injected intramuscularly with a $10^{-2}$ dilution of pool virus. Group 3 were normal animals. Group 4, test animals, were injected intramuscularly with a $10^{-2}$ dilution of pool virus and received $15 \mathrm{mg}$ of $\beta$-phenylserine intraperitoneally daily beginning 24 hours after the virus had been injected. Group 5, virus titration controls, were injected intramuscularly with a $10^{-2}$ dilution of pool virus. Since the toxicity of the borate buffer used in preparing the brcis precluded the assay by mouse inoculation of the virus

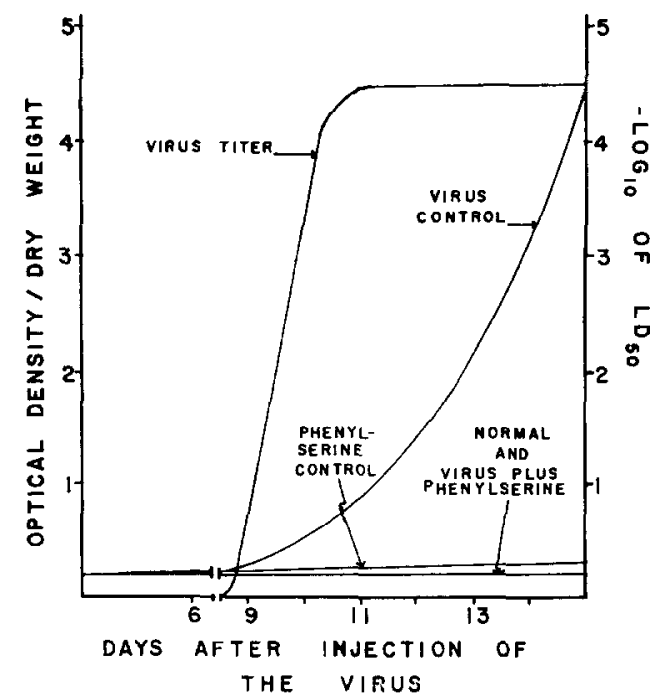

FIG. 4. The effect of rabies infection on the xanthine oxidase activity of rat brain. Rats were injected into the masseter muscle with $90 \mathrm{LD}_{50}$ of rabies virus. On alternate days two animals from each group were killed and xanthine oxidase activity was determined. The amount of virus in the brains was measured by intracerebral inoculation of mice. Animals treated with $\beta$-phenylserine began receiving daily injections intraperitoneally (15 $\mathrm{mg} / \mathrm{day}$ ) 24 hours after infection. present in the brain suspension, it was necessary to use this fifth group of animals to determine the time of appearance of virus in the brains of infected animals.

Two animals from each of the first four groups were sacrificed $2 \frac{1}{2}$ hours after the virus had been injected, 24 hours later, and then on alternate days, and the xanthine oxidase activity of the brains was determined. Each point on the graph (Fig. 4) represents the mean of the activity (expressed as optical density per gram dry weight brain tissue) in the 2 animals. Determinations for each animal were made in triplicate. On the ninth day the xanthine oxidase activity in the virus-control animals began to increase until it reached a maximum when the animals were close to death. The animals of group 5 were sacrificed on alternate days and homogenates of their brains injected into mice to assay for virus.

It is obvious that the effect of rabics on the xanthine oxidase activity of rat brains is similar to that reported by Bauer and Bradley in mouse brains. However, in normal animals $\beta$-phenylserine did not decrease the enzyme activity of rat brain as $\beta$-2-thienylalanine did in rat liver.

\section{DISCUSSION}

Evidence has been presented to show that $\beta$-phenylserine inhibits the development of rabies in rats. Consistently, in experiments involving more than 700 animals, it was possible to demonstrate protection against $40-100 \mathrm{LD}_{50}$ of virus, and in some cases as much as $230 \mathrm{LD}_{50}$. The prophylactic effect was greatest when administration of the compound was begun 1-3 days before challenge; however, some protection could be obtained when treatment was delayed 2448 hours after injection of the virus.

In the animal injected with rabics virus, $\beta$-phenylserine may act in one or more of the following ways: (1) at the site of inoculation, either to inactivate the virus directly or to prevent adsorption of the virus onto a susceptible cell; (2) on the normal defense mechanisms of the host; (3) intracellularly to prevent the formation of new virus particles. 
If $\beta$-phenylserine were combining with the free virus to inactivate or prevent its adsorption onto a susceptible host cell, one would expect inhibition of the virus when it was mixed with the compound before injection. This was not found to be the case. There was no apparent difference in discase manifested either in animals injected with rabies virus diluted in gelatin saline or in $\beta$-phenylserine. Furthermore, protection was demonstrated when the compound was administered to the animals 24 hours after the virus had been injected. It is unlikely that after 24 hours enough free virus exists in the tissue so that its inactivation could seriously alter the course of the disease.

The activity of $\beta$-phenylserine is probably directed against the intracellular multiplication of the rabies virus. Dickinson and Thompson (1957) found that $\beta$-phenylserine was acting during the first half of the latent period of influenza A virus multiplication in chorioallantoic membrane fragments. Furthermore, the addition of phenylalanine reversed the inhibition. The fact that protection is obtained only when the administration of the compound is begun before or 24-48 hours after injection of the virus may indicate that it is acting during the first stages of infection in this system.

The inhibition of rabies virus in rats may be the result of a direct interference with the incorporation of phenylalanine or tyrosine into new virus protein. The fact that both phenylalanine and tyrosine reversed the inhibition indicates that there is a relationship between the two with which $\beta$ phenylserine interferes. Since the rat forms most of its tyrosine from phenylalanine, $\beta$-phenylserine may be inhibiting phenylalanine hydroxylase. Compounds structurally related to $\beta$-phenylserine but lacking either the amino, hydroxy, or phenyl groups were not active in preventing the development of the disease.

The inhibition of lesion formation by vaccinia and myxoma viruses in the rabbit has been demonstrated. $\beta$-Phenylserine did not completely prevent the development of myxomatosis but it did retard its course. As in the case of rabies, symptoms of myxoma virus infection were inhibited by intra- peritoneally administered $\beta$-phenylserine, and the mechanisms involved could be similar.

The role of xanthine oxidase in the formation of new virus is not known. Although it has been possible to show increased activity in the brains of infected rats, we cannot say whether this is related to the actual participation of the enzyme in the formation of new virus or whether the increase is due to the catabolic activity of inflammatory cells acting on nucleoprotein released by damaged cells. However, Bauer (1947) and Bauer and Bradley (1956) have presented evidence against this possibility. They showed that the extent of the increase in enzyme activity was a characteristic of each particular virus tested, and so, unless one assumes a quantization of the inflammatory response to each virus disease, the catabolic activities of phagocytic cells cannot entirely account for the increase.

It was not possible to demonstrate any effect of $\beta$-phenylserine on the xanthine oxidase activity of rat brain. Following the administration of the compound to normal animals there was no measurable change, and treated rats which had been injected with virus also showed no deviation from the normal. Therefore, it is impossible to state whether the compound's inhibitory action is directed against the xanthine oxidase of the brain to prevent its increase or whether the failure to detect an increase in treated animals is due to the inhibition of some other mechanism which precedes the enzyme's increased activity. Xanthine oxidase is a transfering enzyme. The increased activity may be due to the oxidation of reduced groups in the virus, the purines of the damaged cells supplying the oxygen. Therefore, since $\beta$-phenylserine inhibition would result in a decreased amount of tissue destruction by the virus, the activity of the enzyme would not be increased.

\section{REFERENCES}

Bauer, D. J. (1947). Dehydrogenase activity in virus infections. Brit.J. Exptl. Pathol. 28, 440.

Bauer, D. J., and Braduey, P. L. (1956). The xanthine oxidase groups. A phenomenon associated with the multiplication of neurotropic viruses. Brit.J. Exptl. Pathol. 37, 447. 
Drckinson, L., and Thompson, M. J. (1957). The antiviral action of threo- $\beta$-phenylserine. Brit. $J$. Pharmacol. 12, 66.

Eagle, H., Piez, K. A., and Fleischman, R. (1957). The utilization of phenylalanine and tyrosine for protein synthesis by human cells in tissue culture. J. Biol. Chem. 228, 847.

HosLey, R. (1955). Factors affecting the propagation of rabies virus in tissue culture. Thesis. University of Michigan, Ann Arbor.

Kligler, I. J., and Bernkopf, H. (1941). Studies on the cultivation and antigenic characters of rabies virus. $A m . J . H y g . \mathbf{B 3 3}, 1$.

Reed, L. J., and Muench, H. (1938). A simple method of estimating fifty per cent endpoints. Am.J.Hyg. 27, 493.

Roberts, E., Franked, S., and Harmon, P. J. (1950). Amino acids of nervous tissue. Proc. Soc, Exptl. Biol. Med. 74, 383.

Younathan, E. S., Frieden, E., and Dittuer, $K$. (1956). Sensitivity of rat liver xanthine oxidase to amino acid analogues. J. Biol. Chem. 219, 531. 